Difficult Decisions

\title{
Resistant duodenal ulcer: when, why and what to do?
}

\author{
R.P. Walt ${ }^{1}$ and T.K. Daneshmend ${ }^{2}$ \\ ${ }^{1}$ Department of Medicine, Queen Elizabeth Hospital, Birmingham B15 2TH and ${ }^{2}$ Department of Therapeutics, \\ Queen's Medical Centre, Nottingham NG7 2UH, UK.
}

\section{Introduction}

Duodenal ulceration is a chronic disease the causes of which remain unknown. Current medical treatment interrupts the natural history and accelerates ulcer healing. It does not cure ulcers. All duodenal ulcers are generally considered together even though pathophysiological mechanisms differ from patient to patient. It should not be surprising that some duodenal ulcer patients respond relatively poorly. However, duodenal ulcers which do not heal in the 'usual' time have traditionally been labelled as difficult, refractory, intractable, stubborn, recalcitrant, persistent, or resistant. There is no agreement on the definition of resistance and such patients may merely represent one extreme of the 'normal' ulcer population. For the purposes of this article, our definition of resistant duodenal ulcer is: The failure of a duodenal ulcer to heal after two months of full-dose treatment with an $\mathrm{H}_{2}$-receptor antagonist.

\section{Frequency of resistant ulceration}

Cimetidine given for 495 episodes of duodenal ulceration resulted in $83 \%$ and $93 \%$ healing after two and three months, respectively. ${ }^{1}$ Thus $17 \%$ or $7 \%$ of duodenal ulcers could be regarded as refractory depending on your 'pet' definition. In other studies with $\mathrm{H}_{2}$ antagonists, $95 \%$ of duodenal ulcers were healed by two months ${ }^{2}$ and review of many healing trials suggests that an overall figure for non-healed duodenal ulcers may be somewhat higher at $10 \%,{ }^{3,4}$ though in individual studies the figure may be as low as $3 \% .{ }^{5}$ As a consequence of the relative rarity of resistant duodenal ulcer, few studies have improved our understanding or have compared the available treatment options.

Correspondence: R.P. Walt, M.D., M.R.C.P.

Received: 16 November 1987
Many people include ulcer relapse as evidence of treatment failure or resistance. Unfortunately relapse of duodenal ulcer is even less well understood and available data do not allow us to distinguish between expected and unexpected relapse. ${ }^{6}$ A recent study has shown that asymptomatic relapse and subsequent healing are common during maintenance and that most maintenance trials have probably underestimated true ulcer recurrence by nearly half. ${ }^{7}$ There is also an unsubstantiated belief that most ulcers which recur within a few days of stopping treatment had never really healed and were missed by endoscopists. For these reasons we will not consider failure of long-term treatment any further.

It is evident that the frequency of resistant duodenal ulcers changes with alternative definitions. Ours is arbitrary and should be reconsidered as newer drugs become available. It could be argued that no ulcer should be labelled as resistant until it has failed to heal during treatment with the most potent gastric anti-secretory compounds such as the proton pump inhibitor omeprazole.

\section{What makes some duodenal ulcers resistant?}

In many studies lower healing rates for duodenal ulcer are found in those patients who are males, are old, smoke, have large ulcers, consume analgesics, have low fasting serum gastrin, have high maximal acid output in response to pentagastrin, and have nocturnal hypersecretion of gastric acid. ${ }^{8-15}$ Of these various factors, smoking is thought to be most important in delaying ulcer healing and predicting relapse while the other factors are much less consistent predictors. Indeed, in one study ${ }^{16}$ there were no clinical features that could distinguish between patients with responsive or refractory ulcer. In another investigation ${ }^{1}$ comparing 66

(C) The Fellowship of Postgraduate Medicine, 1988 
refractory with 105 responsive ulcer patients, there was no difference in sex ratio, smoking habits, ulcer number, or basal and maximum secretion of acid and pepsin. However, refractory patients in this particular group were more likely to be younger, have a large ulcer, a family history of peptic ulcer and to have bled from their ulcer in the past. In addition, there was no difference in the reduction of acid secretion by cimetidine.

By contrast, Gledhill investigated relatively nonresponsive patients and found that cimetidine in usual or double dose was less able to suppress nocturnal gastric secretion compared to unselected duodenal ulcer patients. ${ }^{17}$ The non-responders to cimetidine were rendered hypochlorhydric by addition of atropine. Additional anticholinergic drug has been found by others ${ }^{18}$ to enhance the antisecretory effects of $\mathrm{H}_{2}$ antagonists. More recently a study showed that patients with resistant ulcers were likely to have an increased basal acid output, those with a basal acid output greater than $10 \mathrm{mEq} / \mathrm{h}$ being unlikely to show ulcer healing on standard dose ranitidine. ${ }^{19}$ However, these resistant ulcers healed with increasing ranitidine dosage (mean $650 \mathrm{mg} /$ day, range 600 to $900 \mathrm{mg} /$ day). ${ }^{19}$

Formal investigations are awaited to test the hypothesis that failure to respond to ulcer treatment is due to colonization of the mucosa by Campylobacter pylori. The good general response of resistant cases to colloidal bismuth (toxic to C. pylori) is the first supportive evidence.

\section{Diagnosis of resistant duodenal ulceration}

Very occasionally ulcers fail to heal for identifiable reasons. It is likely that some patients simply fail to take treatment at all or at the correct dose. In addition, endoscopy may have identified rare causes of duodenal ulceration including Crohn's disease, tuberculosis, neoplasia or cytomegalovirus infection in the immunocompromised patient. The fasting plasma gastrin concentration should be measured off treatment and if raised, other investigations to exclude the Zollinger-Ellison syndrome should follow. Similarly, the serum calcium should be checked to exclude primary hyperparathyroidism.

\section{Practical management of the resistant ulcer}

Advice of a general nature is usually given: to stop smoking and to discontinue non-steroidal antiinflammatory drugs where possible. However despite medical good intentions we neither know how many patients with resistant ulcer manage to stop smoking nor whether this manoeuvre results in acceleration of ulcer healing. Present therapeutic options include (a) continuing the same $\mathrm{H}_{2}$ antagonist for longer, perhaps at a higher dose, (b) changing to another $\mathrm{H}_{2}$ antagonist, (c) adding another agent, (d) changing to another conventional agent, and (e) surgery.

Continuing the same $\mathrm{H}_{2}$ antagonist for a longer period at a higher dose is not tremendously successful. Follow-up of 65 patients with refractory ulcer showed that $60 \%$ healed after 4 to 14 (mean 7.4) months on cimetidine (at two or three times the usual dose), while the remaining $40 \%$ did not even heal after a mean of 9.4 months. ${ }^{1}$ Another trial found that increasing doses of ranitidine, however, was successful. ${ }^{19}$

On present evidence changing to another $\mathrm{H}_{2}$ antagonist probably has little more to offer than increasing the dose of the current drug. Conventional doses of cimetidine have less of an antisecretory effect than ranitidine, while the newer $\mathrm{H}_{2}$ antagonists famotidine and nizatidine are probably no more effective than ranitidine. In one study ${ }^{20}$ standard doses of cimetidine and ranitidine produced similar healing rates in patients with resistant ulcer. However, there is reasonable evidence that ulcer healing is directly proportional to the potency of antisecretory effect at night ${ }^{21}$ and therefore trials comparing larger than usual bedtime or evening doses $\mathrm{H}_{2}$ antagonists may be worthwhile.

Addition of another anti-ulcer drug while continuing the current $\mathrm{H}_{2}$ antagonist at standard or higher doses may bring about greater reduction in gastric acidity. This may be achieved by the addition of an anticholinergic, or high dose antacids. ${ }^{22-23}$ Such an approach has not convincingly been shown to improve healing rates in patients with resistant duodenal ulcers. ${ }^{24}$ Other combinations such as an $\mathrm{H}_{2}$ antagonist plus drugs which 'improve mucosal defence', e.g. sucralfate and bismuth chelate, have not been formally tested in clinical trials.

Another strategy is to change from $\mathrm{H}_{2}$ antagonists to one of a number of drugs which heal ulcers by mechanisms other than reduction of gastric acid or vice versa. The bismuth chelate, tripotassium dicitrato bismuthate (TDB), accelerates ulcer healing and, following healing with TDB, relapse is less frequent than after cimetidine ${ }^{6}$ or ranitidine. ${ }^{5}$ Cimetidine-resistant ulcers appear to respond well to TDB. ${ }^{25,26}$ Fifty two patients with resistant duodenal ulcers given cimetidine $1.2 \mathrm{~g}$ /day, $2 \mathrm{~g} /$ day or TDB $480 \mathrm{mg} /$ day, had 4-week healing rates of $39 \%, 44 \%$ and $82 \%$, respectively. ${ }^{26}$ After 8 weeks, these figures had risen to $65 \%, 75 \%$ and $94 \%$, respectively. These studies suggest that resistant duodenal ulcers may be more responsive 
to an agent which improves mucosal defences than one which reduces gastric acid. There is less compelling evidence for the use of sucralfate (aluminium octasulphate) as sole agent in resistant duodenal ulcers.

Surgery for resistant duodenal ulcer may appear a valid therapeutic option, but the results are not always encouraging. By and large surgery produces hypochlorhydria similar to that produced pharmacologically with $\mathbf{H}_{2}$-receptor antagonists and it would therefore be surprising if surgical results were exceptional in truly resistant cases. In a recent report of highly selective vagotomy for resistant cases there was a $16 \%$ recurrence rate at 2 years, which increased to $37 \%$ at 5 years. ${ }^{27}$ Other studies which specifically investigated surgery in resistant cases have ranged from poor results, ${ }^{1}$ or $44 \%$ recurrence over five and a half years ${ }^{28}$ to good results with only $5 \%$ recurrence. ${ }^{29}$ In another surgical trial as many patients required long-term medical therapy post-surgery as were referred for surgery because of failed medical treatments. ${ }^{30}$ There is undoubtedly a place for surgery in the few patients who refuse continued medical therapy although the arrival of more potent antisecretory drugs may rob surgeons of these patients.

\section{Future possibilities}

A number of synthetic prostaglandin analogues (for example, misoprostol, enprostil) are under evaluation and may become available for clinical use in the near future. In general, they have produced ulcer healing rates lower than the $\mathrm{H}_{2}$ antagonists and it appears likely that their 'cytoprotective' properties are of lesser importance than the antisecretory ones. ${ }^{31}$ There are no comparative clinical trials using prostaglandin analogues in resistant duodenal ulcer. Of ulcers refractory to 8 weeks' cimetidine or ranitidine, only $42 \%$ healed with misoprostol compared with $20 \%$ on placebo. ${ }^{32}$ It is unlikely that they will be of benefit if used alone for such patients.

The proton pump inhibitor omeprazole rapidly almost produces achlorhydria throughout 24 hours in patients with duodenal ulcer. ${ }^{33}$ Omeprazole also heals virtually all duodenal ulcers within 4 weeks. ${ }^{34,35}$ If it were to become generally available, the number of 'resistant' ulcers would be much reduced. Ulcers resistant to at least 3 months therapy with $\mathrm{H}_{2}$ antagonists all healed on omeprazole $40 \mathrm{mg}$ once daily. ${ }^{36}$ Nine out of 11 of these resistant duodenal ulcers healed within 2 weeks and the remainder had healed after 4 weeks.

\section{Conclusions}

Differences in definition of therapeutic resistance and the scarcity of truly refractory duodenal ulcer has meant that data to improve our understanding are limited. No consistent differences have been found which enable identification of resistant ulceration before starting treatment. Thus the definition and therefore diagnosis depends on observing failure to respond to normally adequate treatment. Presently, changing from an $\mathbf{H}_{2}$ antagonist to colloidal bismuth offers the patient the best chance. However, when omeprazole or other highly potent antisecretory drugs are available duodenal ulcer healing should almost be guaranteed. At that time the definition of therapeutic resistance will have to be reviewed.

\section{References}

1. Bardhan, K.D. Refractory duodenal ulcer. Gut 1984, 25: 711-717.

2. Howden, C.W., Jones, B.D. \& Hunt, R.H. Nocturnal doses of $\mathrm{H}_{2}$-receptor antagonists for duodenal ulcer. Lancet 1985 , i: 647-648.

3. Meyrick-Thomas, J. \& Misiewicz, J.J. Histamine $\mathbf{H}_{2}$ receptor antagonists in the short term and long term treatment of duodenal ulcer. Clin Gastroenterol 1984 13: 501-541.

4. Legerton, C.W. Duodenal and gastric ulcer healing rates: a review. Am J Med 1984, 77 (Suppl 5B): 2.

5. Lee, F.I., Samloff, I.M. \& Hardman, M. Comparison of tripotassium dicitrato bismuthate tablets with ranitidine in healing and relapse of duodenal ulcers. Lancet 1985 , i: $1299-1302$.

6. Hamilton, I., O'Connor, H.J., Wood, N.C., Bradbury, I. \& Axon, A.T.R. Healing and recurrence of duodenal ulcer after treatment with tripotassium dicitrato bismuthate (TDB) tablets or cimetidine. Gut 1986, 27: 106-110.

7. Boyd, E.J.S., Penston, J.G., Johnstone, D.A. \& Wormsley, K.G. What really happens during maintenance therapy of duodenal ulcer? Gut 1987, 28: A1341.

8. Sonnenberg, A., Muller-Lissner, S.A. Vogel, E. et al. Predictors of duodenal ulcer healing and relapse. Gastroenterology 1981, 81: 1061-1067. 
9. Lam, S.K. \& Koo, J. Accurate prediction of duodenal ulcer healing rates by discriminant analysis. Gastroenterology 1983, 85: 403-412.

10. Lam, S.K., Lai, C.L., Lee, L.N.W. et al. Factors influencing healing of duodenal ulceration. Dig Dis Sci 1985, 30: 45-51.

11. Gledhill, T., Buck, M., Paul, A. \& Hunt, R.H. Cimetidine or vagotomy? Comparison of the effects of proximal gastric vagotomy, cimetidine and placebo on nocturnal intragastric acidity and acid secretion in patients with cimetidine resistant duodenal ulcer. $\mathrm{Br} J$ Surg 1983, 70: 704-706.

12. Galmiche, J.-P., Pranvonez, J.-L., Denis, P. et al. Does nocturnal gastric $\mathrm{pH}$ monitoring help to predict ulcer healing in severe duodenal ulcers treated with ranitidine? Gastroenterol Clin Biol 1985, 9: 583-589.

13. Korman, M.G., Hanskey, J., Eaves, E.R. \& Schmidt, G.T. Influence of cigarette smoking on healing and relapse in duodenal ulcer disease. Gastroenterology 1983, 85: 871-874.

14. Sontag, S., Graham, D.Y., Belisto, A. et al. Cimetidine, cigarette smoking and recurrence of duodenal ulcer. $N$ Engl J Med 1984, 311: 689-695.

15. Kikendall, J.W., Evaul, J. \& Johnson, L.F. Effect of cigarette smoking on gastrointestinal physiology and non-neoplastic digestive disease. J Clin Gastroenterol 1984, 6: 65.

16. Guslandi, M. More about refractory duodenal ulcers. Gut 1984, 25: 1433.

17. Gledhill, T., Buck, M. \& Hunt, R.H. The effect of no treatment, cimetidine $1 \mathrm{~g} /$ day, cimetidine $2 \mathrm{~g} /$ day, and cimetidine combined with atropine on nocturnal gastric secretion in cimetidine nonresponders. Gut 1984, 25: 1211-1216.

18. McCarthy, D.M. Report on the U.S. experience with cimetidine in the Zollinger Ellison syndrome and other hypersecretory states. Gastroenterology 1978, 74: 453-455.

19. Collen, M.J., Stanczak, V.J. \& Ciarleglio, C.A. Basal acid output in patients with refractory duodenal ulcers. Gastroenterology 1987, 5: 1351.

20. Quatrini, M., Basillsio, G. \& Bianchi, P.A. Treatment of cimetidine resistant chronic duodenal ulcers with cimetidine or ranitidine: a randomised multicentre study. Gut 1984, 25: 1113-1117.

21. Jones, D.B., Howden, C.W., Burget, D.W., Kerr, G.D. \& Hunt, R.H. Acid suppression in duodenal ulcer: a meta-analysis to define optimal dosing with antisecretory drugs. Gut 1987, 28: 1120-1127.

22. Peterson, W.L., Barnett, C., Feldman, M. \& Richardson, C.T. Reduction of twenty-four-hour gastric acidity with combination drug therapy in patients with duodenal ulcer. Gastroenterology 1979, 77: 1015-1020.
23. Feldman, M., Richardson, C.T., Peterson, W.L. Walsh, J.H. \& Fordtran, J.S. Effect of low dose propantheline on food stimulated gastric acid secretion. $N$ Engl J Med 1977, 297: 1427-1430.

24. Bardhan, K.D., Thompson, M., Bose, K. et al. Combined histamine $\mathrm{H}_{2}$ and antimuscarinic receptor: blockade in the treatment of refractory duodenal ulcer. Gut 1986, 27: A606.

25. Lam, S.K., Lee, N.W., Koo, J., Hui, W.M., Fok, K.H. \& Ng, M. Randomised cross over trial of tripotassium dicitrato bismuthate versus high dose cimetidine for duodenal ulcers resistant to standard dose of cimetidine. Gut 1984, 25: 703-706.

26. Bianchi Porro, G., Parente, F. \& Lazzaroni, M. Tripotassium dicitrato bismuthate (TDB) versus two different dosages of cimetidine in the treatment of resistant duodenal ulcers. Gut 1987, 28: 907-911.

27. Primrose, J.N. \& Johnston, D. Is highly selective vagotomy effective for the duodenal ulcer which fails to heal on $\mathrm{H}_{2}$ receptor antagonists? Gastroenterology 1987, 92: 1580 .

28. Hansen, J.H. \& Knigge, V. Failure of proximal gastric vagotomy for duodenal ulcer resistant to cimetidine. Lancet 1984. ii: 84-86.

29. Pickard, W.R. \& Mackay, C. Early results of surgery in patients considered to be cimetidine failures. $\mathrm{Br} J$ Surg 1984, 71: 67-68.

30. Strom, M., Bodemar, G., Lindhagen, S., Sjodahl, R. \& Walan, A. Cimetidine or parietal cell vagotomy in patients with juxtapyloric ulcers. Lancet 1984, ii: 894 897.

31. Hawkey, C.J. \& Walt, R.P. Prostaglandins for pept ulcer disease: a promise unfulfilled. Lancet 1986, 1084-1087.

32. Newman, R.D., Gitlin, N., Lacayo, E. et al. Misoprostol in the treatment of duodenal ulcer refractory to $\mathrm{H}_{2}$ blocker therapy; A placebo controlled multicentre double blind randomized trial. Am J Med 1987, 83 (Suppl 1a): 27-31.

33. Walt, R.P., Gomes, M., Wood, E.C., Logan, L.H. \& Pounder, R.E. Effect of daily oral omeprazole on 24 hour intragastric acidity. $\mathrm{Br}$ Med J 1983, 287: 12-14.

34. Gustavsson, S., Loof, L., Adami, H.O., Nyberg, A. \& Nyren, O. Rapid healing of duodenal ulcers with omeprazole. Dose comparative study. Lancet 1983, ii: 124-125.

35. Lauritsen, K., Rune, S.J., Bytzer, P. et al. Effect of omeprazole and cimetidine on duodenal ulcer. $N$ Engl J Med 1985, 312: 958-961.

36. Tytgat, G.N.J., Lamers, C.B.H.W., Hameeteman, W., 윽 Jansen, J.M.B.J. \& Wilson, J.A. Omeprazole in peptic ulcers resistant to histamine $\mathrm{H}_{2}$-receptor antagonists. Aliment Pharmacol Ther 1987, 1: 31-38. 